\title{
The effect of two feeding systems for growing pigs on growth performance, carcass and meat quality
}

\author{
A. Lyczyński', Z. Bartkowiak ${ }^{1}$, E. Pospiech ${ }^{2}$, M. Urbaniak ${ }^{3}$, \\ E. Rzosińska ${ }^{1}$ and A. Frankiewicz ${ }^{3}$ \\ 'Department of Animal Origin Materials, \\ 'Institute of Meat Technology, \\ ${ }^{3}$ Department of Animal Nutrition and Feed Management, \\ August Cieszkowski Agricultural University \\ Wotynska 33, 60-637 Poznań, Poland
}

\begin{abstract}
Twenty-nine growing pigs were fed using two regimes: ad libitum or ad libitum/rationed diet from $65 \mathrm{~kg}$, with grower rations adjusted to the needs of fatteners at changing body weight. Pigs fed ad libitum reached the slaughter weight of approx. $105 \mathrm{~kg} 14$ days earlier than those kept under the rationed diet system. Average daily weight gain of pigs fed ad libitum was higher by $0.15 \mathrm{~kg}$ and the feed conversion ratio was slightly higher $(0.07 \mathrm{~kg})$. Slaughter and meat quality traits were similar in both feeding systems, except for a slightly higher crude protein content $(0.49 \%)$ in the meat of pigs fed under the rationed diet regime.
\end{abstract}

KEY WORDS: pigs, feeding system, fattening, carcass quality, meat quality

\section{INTRODUCTION}

Investigations being carried out in Poland at present focus on improving fattening, slaughter and meat quality traits, primarily by upgrading the genetic material (Różycki, 1999) and by optimizing environmental conditions (Wajda, 1998). Feeding is one of the most important environmental factors having a major effect on fattening and slaughter traits as well as meat quality (Zessin et al., 1961; Fandrejewski, 1995, 1999; Wood et al., 1998). A subject of research work can be found in the available literature that indicates that the system of pig nutrition can have an important impact on animal productivity, carcass morphological composition and meat value (Blanchard, 1995; Wood et al., 1998). Very few 
investigations in this area have been carried out in our country (Fandrejewski, 1995, 1999; Eckert , 2001).

Therefore, the objective of this study was to determine the effect of two feeding systems, namely ad libitum and ad libitum/rationed diet on growth rate, feed utilization, slaughter value and meat quality of fatteners.

\section{MATERIAL AND METHODS}

Twenty-nine crossbred piglets of Polish Large White $x$ Polish Landrace constituted the experimental material. The study was started at a liveweight of $30 \mathrm{~kg}$. It was divided into two stages: the first period, from $30 \mathrm{~kg}$ to $65 \mathrm{~kg}$ (when the animals were kept two per pen) and the second, from $65 \mathrm{~kg}$ to approx. $105 \mathrm{~kg}$ (when each animal was kept in a separate pen). The ad libitum system was maintained during the first period of fattening. The experimental ration contained 13.5 MJ ME, $18.5 \%$ crude protein and $1.0 \%$ lysine. In the second period of fattening, the animals were divided into two groups, one fed ad libitum and the other kept under the rationed diet system. The diet was adjusted to the needs of fatteners at changing body weights and was changed every two weeks. The feed ration in this period contained $12.5 \mathrm{MJ} \mathrm{ME}, 16.0 \%$ crude protein and $0.86 \%$ lysine. Growth rate was controlled every two weeks, feed consumption, daily. After pigs reached a weight of approx. $105 \mathrm{~kg}$ they were subjected to a 12-h fast prior to slaughter. The pre-slaughter rest lasted for approx. $1 \mathrm{~h}$. Animals were slaughtered in accordance with technological standards.

Standard methods were used to determine the basic chemical composition of feeds (AOAC, 1990). The amino acid composition of feeds was analyzed using an automatic amino acid analyzer AAA 839 (Kovo, Czech Republic) according to the methods given by Urbaniak et al. (1998). Meatiness was evaluated using two methods: immediately after slaughter with the ULTRAFOM 200 apparatus, and after $24 \mathrm{~h}$ on the medium gluteal muscle using an electronic gauge. Colour in the $\mathrm{L}^{*}, \mathrm{a}^{*}, \mathrm{~b}^{*}$ system was determined with a Minolta colorimeter.

The SAS program was used for the statistical analysis of the data (SAS, 1989).

\section{RESULTS}

Table 1 presents the results of fattening traits in case of pigs fed ad libitum and under the ad libitum/rationed diet system. Pigs fed ad libitum reached the slaughter weight of $105 \mathrm{~kg} 14$ days earlier than those kept under the rationed diet system. The differences between groups in terms of daily weight gains were statistically significant $(\mathrm{P}<0.05)$. The average daily weight gain for pigs fed ad libitum was 
TABLE 1

Effect of two feeding systems on selected fattening traits

\begin{tabular}{|c|c|c|c|c|}
\hline \multirow{3}{*}{ Traits } & \multicolumn{4}{|c|}{ Feeding systems } \\
\hline & \multicolumn{2}{|c|}{ ad libitum } & \multicolumn{2}{|c|}{ ad libitum/rationed } \\
\hline & $x$ & $\mathrm{sd}^{*}$ & $\dot{x}$ & sd \\
\hline Number of animals & \multicolumn{2}{|c|}{13} & \multicolumn{2}{|c|}{16} \\
\hline Daily weight gain, $\mathrm{kg}$ & $0.917^{\mathrm{a}}$ & 0.20 & $0.766^{b}$ & 0.14 \\
\hline Feed conversion ratio, kg & 3.12 & 0.32 & 3.05 & 0.37 \\
\hline Fattening days & 84 & 19 & 98 & 18 \\
\hline
\end{tabular}

a, b means in the same row bearing different superscripts differ $\mathrm{P}<0.05$

* sd - standard deviation

$0.15 \mathrm{~kg}$ higher and the feed conversion ratio was slightly higher $(0.07 \mathrm{~kg})$ in comparison with the fatteners kept under the other system.

Table 2 presents the analyzed slaughter traits and meat quality. Significant differences $(\mathrm{P}<0.05)$ between the feeding systems were found only for crude protein content. Meat of fatteners kept under the ad libitum/rationed diet system contained $0.49 \%$ more crude protein than in the case of pigs fed ad libitum. The other investigated traits did not exhibit significant differences. However, it needs to be stated

TABLE 2

Effect of two fecding systems on selected carcass and meat quality

\begin{tabular}{|c|c|c|c|c|}
\hline \multirow{3}{*}{ Traits } & \multicolumn{4}{|c|}{ Fceding systems } \\
\hline & \multicolumn{2}{|c|}{ ad libitum } & \multicolumn{2}{|c|}{ ad libitum/rationed } \\
\hline & $\ddot{x}$ & $\mathrm{sd}^{*}$ & $\bar{x}$ & sd \\
\hline Number of animals & \multicolumn{2}{|c|}{13} & \multicolumn{2}{|c|}{16} \\
\hline Meatiness - ULTRAFOM 200, \% & 49.63 & 4.70 & 48.94 & 4.16 \\
\hline Meatiness $24 \mathrm{~h}$ - electronic gauge, $\%$ & 49.98 & 5.54 & 48.39 & 4.69 \\
\hline $\mathrm{pH}_{45}-$ of loin & 6.30 & 0.34 & 6.23 & 0.30 \\
\hline $\mathrm{pH}_{45}-$ of ham & 6.52 & 0.26 & 6.32 & 0.35 \\
\hline $\mathrm{pH}_{24 \mathrm{~h}}-$ of loin & 5.58 & 0.20 & 5.51 & 0.17 \\
\hline $\mathrm{pH}_{24 \mathrm{~h}}-$ of ham & 5.63 & 0.20 & 5.59 & 0.16 \\
\hline Colour $\mathrm{L}^{\circ}$ & 55.86 & 5.34 & 55.51 & 2.76 \\
\hline$a^{*}$ & 5.28 & 1.73 & 5.56 & 1.31 \\
\hline$b^{*}$ & 3.69 & 2.01 & 3.38 & 1.53 \\
\hline Crude protein content, $\%$ & $22.50^{\mathrm{a}}$ & 0.25 & $22.99^{\mathrm{b}}$ & 0.62 \\
\hline Water content, $\%$ & 74.56 & 0.62 & 74.48 & 0.87 \\
\hline Fat content, $\%$ & 1.67 & 0.67 & 1.48 & 0.33 \\
\hline
\end{tabular}

a.b means in the same row bearing different superscripts differ $\mathrm{P}<0.05$

* sd - standard deviation 
that in case of the ad libitum feeding system, slightly improved carcass leanness was obtained, irrespective of the method applied. Meat reaction $\left(\mathrm{pH}_{45}\right)$, regardless of muscle type, showed more favourable values in the case of pigs fed ad libitum. Meat of the pigs fed ad libitum had a slightly lighter colour and contained $0.19 \%$ more fat, which has a more favourable cffect on organoleptic properties, especially tenderness.

\section{DISCUSSION}

In this study, the influence of two feeding systems on growth rate, feed conversion ratio, and selected slaughter traits was evaluated. The animals' growth rate in both experimental groups was relatively high, but a significantly higher daily weight gain and slightly poorer feed conversion ratio was observed in the case of fatteners fed ad libitum in the entire period of the study. Zessin et al. (1961), Blanchard (1995) and Wood et al. (1998) reported similar results.

Tenderness is one of the basic sensory traits of meat, determining its quality. It is related to, among others, intramuscular fat content (Zessin et al., 1961; Wood et al., 1998). A slightly higher but non-significant content of intramuscular fat was found in our study in pigs fed ad libitum, which is corroborated by the results reported by Zessin et al. (1961), Blanchard (1995), Wood et al. (1998). There are several reports that intramuscular fat content enhances the juiciness while biting and chewing, as it stimulates salivation (Wood et al., 1998).

Blanchard (1995), both in his own study and quoting results reported by other authors, showed that feeding pigs under the ad libitum system in comparison with the restrictive system has an advantageous effect on most analyzed fattening and slaughter traits within a very wide range of body weight, i.e. from $30 \mathrm{~kg}$ to approx. $85 \mathrm{~kg}$. On the other hand, Pospiech et al. (1998), Łyczyński and Pospiech (2000), Łyczyński et al. (2000), reported losses resulting from various meat defects, which significantly deteriorate its quality as a finished product or a raw material used in meat processing. Moreover, Pospiech et al. (2000) suggested that under the conditions in Polish farms, a carcass meat content of over $55 \%$ has an unfavourable effect on the sensory attributes of the evaluated meat.

Moreover, Zessin et al. (1961) showed that a reduced content of intramuscular fat in the longissimus dorsi muscle resulted simultaneously in a reduction in the subcutaneous fat content, and consequently, during culinary treatment of the meat, significantly deteriorated tenderness, juiciness, and aroma. This was also confirmed by the results of the authors' studies as well as those reported by Blanchard (1995) and Wood et al. (1998), concerning the more advantageous effect of the ad libitum feeding of pigs on fattening and slaughter traits, and meat quality. 


\section{REFERENCES}

AOAC, 1990. Official Methods of Analysis. Association of Official Analytical Chemists. $16^{\text {th }}$ Edition. Arlington, VA

Blanchard P., 1995. Pork quality: How can the eating quality of pork be influenced by management on the farm? Feeding system. Meat Focus Int. 372-375

Eckert R., Szyndler-Nędza M., Tyra M., 2001. Correlations between daily weight gainand meatiness vs feed conversion in ad libitum feed pigs (in Polish). Ann. Anim. Sci. 405, 37-42

Fandrejewski H., 1995. Feeding of meat fatteners (in Polish).Proceedings of the International Scientific Meeting "Current Problems on Pig Production", Olsztyn (Poland), pp. 17-19

Fandrejewski H., 1999. New opinions of feeding growing pigs (in Polish). Proceedings of the International Scientific Conference "Current Problems on Pig Production", Olsztyn (Poland), pp. 20-27

Łyczyński A., Pospicch E., 2000. Factors affecting quality and effectiveness of pork production (in Polish). Meat Economy 6, 52-58

Łyczyński A., Pospiech E., Urbaniak M., Bartkowiak Z., Rzosińska E., Szalata M., Medyński A., 2000. Slaughter value and meat quality of crossbred fatteners (PLW x PL) and (PLW x PL) x Pi (in Polish). Ann. Anim. Sci. 5, Suppl., 104-108

Pospicch E., Borzuta K., Łyczyński A., Plókarz W., 1998. Meat defects and their economic importance. Pol. J. Food Nutr. Sci. 7, 7-20

Pospiech E., Łyczyński A., Urbaniak M., Szalata M., Mikołajczak B., Medyński A., Bartkowiak Z., Rzosińska E., 2000. Evaluation of the relationships between daily weight gain, muscle tissue growth rate and meat tenderness (in Polish). Ann. Anim. Sci. 5, Suppl., 114-118

Różycki M., 1999. Improvement of meatiness of pig races brceding in Poland (in Polish). Ann. Anim. Sci. 3, Suppl., 55-63

SAS, 1989. SAS User's Guide: Statistics. SAS Institute Inc. Cary, NC

Urbaniak M., Frankiewicz A., Łyczyński A., Pospiech E., Wasilewski Z., Jędroszkowiak P., Matyniak J., 1998. The protein and amino acids content of different body components of Polish Merino $\mathrm{x}$ Suffolk rams and ewes at $20 \mathrm{~kg}$ live weight. Ann. Anim. Sci. 25, 105-116

Wood J.D., Enser M., Fischer A.V., Nute G.R., Richardson R.I., Sheard P.R., 1998. Meat quality: an integrated approach for the future. Proceedings of the $15^{\text {th }}$ International Pig Veterinary Society Congress, Birmingham (UK), pp. 103-113

Wajda S., 1998. Effect of pre-slaughter treatment of pigs on meat quality. Pol. J. Food Nutr. Sci. 7 , 115-121

Zessin D.A., Pohl C.V., Wilson G.D., Weir E., Breidenstein B.C., Breidenstein B.B., G Arrigan D.S., 1961. Effect of pre-slaughter dietary stress on the carcass characteristics and palatability of pork. J. Anim. Sci. 20,871-875 


\section{STRESZCZENIE}

\section{Wplyw dwóch systemów żywienia rosnących świń na cechy tuczne, rzeźne i jakość mięsa}

Badania przeprowadzono na 29 wieprzkach mieszańcach wbp x pbz, od początkowej m.c. $65 \mathrm{~kg}$, stosując dwa systemy żywienia tuczników: ad libitum lub ad libitum/dawkowany (od $65 \mathrm{~kg}$ masy ciała) w zależności od wzrastającej masy ciała. Świnie ubijano przy około $105 \mathrm{~kg}$ i oznaczano przyrosty dobowe i zużycie paszy oraz cechy rzeźne i jakość mięsa.

Świnie żywione ad libitum osiąnęły ubojową masę ciała około $105 \mathrm{~kg}$ o 14 dni wcześniej niż żywione systemem ad libitum/dawkowanym. Średni przyrost dobowy świń żywionych ad libitum był o $0,15 \mathrm{~kg}$ większy, przy nieznacznie wyższym $(0,07 \mathrm{~kg})$ zużyciu paszy na $1 \mathrm{~kg}$. Cechy rzeźne i jakościowe mięsa były zbliżone u zwierząt $\mathrm{z}$ obydwóch grup, z wyjątkiem nieznacznie wyższej zawartości białka ogólnego $(0,49 \%)$ w mięsie świń żywionych systemem ad libitum/dawkowanym. 